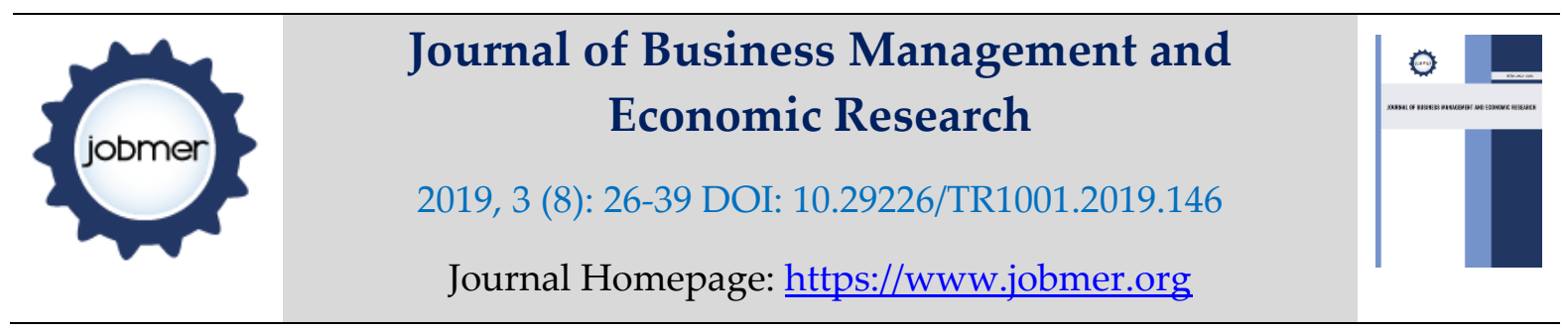

\title{
FACTORS LEADING TO CONFLICTS BETWEEN FARMERS AND PASTORALISTS IN TANZANIA: EVIDENCE FROM KAMBALA VILLAGE IN MOROGORO
}

\section{William Mwalimu}

Assistant Lecturer Department of Management Sciences and Procurement, Ruaha Catholic University, wmwalimu.tz350@gmail.com

\section{Hadija Matimbwa}

Lecturer Department of Management Sciences and Procurement, Ruaha Catholic University, Email hadija.matimbwa@gmail.com

\begin{abstract}
The study was conducted to examine the factors leading to conflicts between farmers and pastoralists in Kambala Village. The work is anchored on the fact that there have been numerous efforts by the government to bring an end to conflicts between farmers and pastoralists but the conflicts continue to persist and escalate resulting into both economic and social difficulties. Covering a sample size of 110 respondents, data was collected using interviews, documentary review, and focus group discussions. Collected data was analysed using both qualitative and quantitative analysis. The findings reveal that environment factors, unethical behaviour, increase in both human and livestock population, overstocking, policy and regulatory deficiencies, nature of approaches used to resolve and manage the conflicts, and other factors are responsible for the recurrence of conflicts between farmers and pastoralists. Drawing from conflict and conflict resolution theories, which advocate for the use of coercive power and participatory approaches to restore peace, respectively; this paper concludes that no single strategy fits all conflicts given the uniqueness of different conflict settings. In light of the results, this paper recommends effective approaches to address farmers-pastoralists conflicts; actors should use both lenses of coercive and participatory approaches and the choice of an appropriate strategy will depend on the context of the conflict since no single approach fits all type of conflicts.
\end{abstract}

Keywords: Conflict, Farmers, Pastoralists 


\section{Background to the problem}

A major problem confronting world peace today from time immemorial is the manifestation of conflicts in different dimensions across the global. Conflict refers to misunderstanding, disagreement or divergence of idea, which result into harm. Delayed resolution of a conflict can lead to coercive measures that suggest forceful victory on either party (Norman, 2013).

Conflicts between farmers and pastoralists are not a new phenomenon. As a matter of fact, conflicts have been reported even in the holy books; reference can be made to the biblical story of Cain, a farmer who killed Abel who was a pastoralist (Benjaminses et al., 2009).

Also, various scholars have reported tensions between farmers and pastoralists in different parts of the world including Africa such as in Bukinafaso between the Mossi farmers and Fulani pastoralist, in Nigeria between the Hausa and Fulani, and in Kenya between the Pokomo (farmers) and Orma (pastoralists) (Massay, 2017). Most of these conflicts are caused by inadequate access to resources, beliefs and values, nature of relationship, territory fortification, language, ethnicity, self-determination, dominance, equality, and revenge. (Deutsch (1991) and Zartaman (2005) cited by Falanta et al., (2018).

In Tanzania, conflicts between farmers and pastoralists have been recurring for a long-time claiming lives of many innocent people, subjecting people to homelessness, causing food insecurity,among others in both communities. Areas such as Kilosa, Mvomero, Ulanga, and Kilombero Districts in Morogoro, Kilindi and Handeni in Tanga Region, Mbarali District in Mbeya, Arumeru and Kiteto in Arusha, Rufiji and Mkuranga in Pwani, Kongwa in Dodoma and Hai in Kilimanjaro are prone to farmers-pastoralists clashes (Mwamfupe, 2015).

The experience in Tanzania shows that conflicts between farmers and pastoralists are most noticeable during drought seasons. During such periods, pastoralists tend to move their herds to destinations far away from their settlements (transhumance) in search for pasture and water although sometimes animals graze on farm crop (Mung'ong'o et al., 2003; Falanta et al., 2018). There has been an increase in the magnitude of conflicts to the extent that state interventions have become necessary. For instance, in Kambala village in Mvomero District, which is a case study, land had to be split between pastoralists and farmers (Mwamfupe, 2015,Semberya 2014).

Despite these efforts by the government, conflicts have been recurring resulting into unbearable outcomes (Fantala et al., (2018). This situation raises a number of questions as to why such conflicts persist. While 
literature observes that the increasing number of conflicts in various areas of farmers-pastoralist is worrisome (Semberya, 2014), what exactly causes the recurrence of this situation is unknown. It might be possible that there are new drivers emerging, the applied strategies in addressing such conflicts are not relevant to the prevailing situation, or the previously identified drivers have not been dealt with accordingly. Based on this backdrop, this paper attempts to examine the factors leading to conflicts between farmers and pastoralists in Kambala village.

\section{Literature Review}

\subsection{Theoretical Framework}

\section{Conflict Theory}

According to the conflict theory, tensions and conflicts arise when resources, status, and power are unevenly distributed between groups in society and these conflicts become the engine of social change (Crassman, 2016,Falanta et al., 2018). In addition, Tonah (2006) maintains that the conflict theory views constant antagonism over economic resources as the fundamental cause of conflict and this usually happens when two or more parties fail to reach a consensus on resources they need.

Karl Marx, through the conflict theory emphasizes the role of coercion and power in producing social order (Crossman, 2013). The theories stress that social order is maintained by domination and power, rather than by consensus and conformity. The wealthy and powerful individuals control material resources and accumulated wealth. They equally control politics and institutions that govern societies.

However, this paper argues that it is not in all contexts that coercive power is appropriate to solve conflicts. In other contexts, participatory approaches are more relevant and effective. This generally suggests that the conflict theory is limited in its scope and may not support situations, which require participatory approaches since it relies on the use of coercive power as a response to conflicts. In this regard, there is a need to reconsider the conflict resolution theory.

\section{The Conflict Resolution Theory}

The conflict resolution theory as a discipline has developed theoretical insights into the nature and resources of conflicts and how conflicts can be resolved through peaceful methods to effectuate durable settlements. Boundless (2016) argues that the conflict resolution theory suggests that human behaviour in social contexts results from conflicts between competing groups. The theory works along Karl Max's contention that "a society is a dynamic entity, which constantly views social life as competition." 
It goes without saying that the conflict resolution theory considers peaceful mechanisms and more participatory approaches in addressing conflicts. This paper suggests that in situations where coercive approaches are not appropriate, the conflict resolution theory is well placed to invoke peaceful settlement of conflicts. Given the fact that we do not live in an ideal world, it is not uncommon to apply both approaches i.e. the coercive approach and the participative approach or a combination of both when dealing with conflicts.

\subsection{Empirical Literature Review}

\section{Factors Leading to Conflict between Farmers and Pastoralists}

Conflicts between farmers and pastoralists have been linked to a number of drivers. Scholars identify various factors (drivers) leading to conflicts such as drought, land use, migration, as well as traditional beliefs and practices (Mwamfupe, 2016; Benjaminsen et al., 2009; Abroulaye et al., 2015). However, the implications of these factors on farmers and pastoralists have been detrimental in most cases.

According to FAO (2005), droughts or periods of unusual low rainfall are part of the expected pattern of precipitation in semi-arid Africa. Thus, one of the serious effects of drought is drying up of water resources and decline of forage for livestock, a situation, which results into conflicts between farmers and pastoralists (Orindi et al., 2007). Climate variability also affects distribution and availability of these resources forcing pastoralists to migrate to areas occupied by farmers. This leads to inevitable conflicts between the two groups. Mancosu et al., (2015) points out that a correlation between droughts and conflict already exist in Africa mainly due to increased competition for water and pasture.

Additionally, land conflicts often have extensive negative effects on economic, social, spatial, and ecological development. This is especially true in developing countries and countries in transition economies where land market institutions are weak and opportunities for economic gain by illegal action are widespread and hence, many poor people lack access to land. Land conflicts can have disastrous effects on individuals as well as on groups and even entire nations (Adelakun, 2015; Wehrmann, 2008). Many conflicts that are perceived to be clashes between different cultures are actually conflicts over land and related natural resources. This means that in most cases people compete for natural resources to enhance their livelihood. Migration from one place to another is a pattern resulting from chronic drought conditions. Initially, this follows pre-established labour migration patterns and may not differ in intensity from areas with established high rates of temporary, circular migration (Judex \&Menz, 2003). In comparison to other 
disasters where few victims consider permanently changing location, Raleigh et al., cited by Falanta et al., (2018) points out that migration is considered the highest in arid areas.

Adeoye (2007) accentuates that pastoralists sometimes engage in deliberate destruction of crops and properties believing that such acts are essential for stock growth/expansion and house prosperity. When farmers on the other hand carry out bush burning for various reasons, pastoralists perceive this as a deliberate attempt to deny livestock access to pasture. Additionally, some pastoralists believe that all livestock in the world belong to them and were given to them by Enkai, (the god). Such beliefs have often aroused misunderstandings between or among communities resulting into inter-tribal conflicts (Banjaminsen et al., 2009).

\section{Methodology}

This study focuses on factors leading to conflicts between farmers and pastoralists at Kambala village in Mvomero District located in Morogoro. The choice of the study area was influenced by the fact that, Kambala is a pastoral village and it is blessed with natural resources, which set the stage for conflicts between farmers and pastoralists. The study employed the cross-section research design, which involves collection of information only once from any given sample of population (Kothari 2008). This design was used because of two main reasons. First, the information gathered from the respondents and documentary review represents the existing situation at the time of the study (Bailey 1994) and the second reason is based on Amin's (2005) observation that the design allows collection of data of given variables at a given time. This ensured that all data required were collected within a short period of time despite a relatively large sample of respondents.

The unit of analysis of this study were the households of farmers and pastoralist in Kambala. Using proportionate sampling, 58 and 52 respondents were selected from the study area respectively. Representatives from each sub-village were selected randomly; this was to avoid bias from the sample selected. The researcher prepared checklists for interview where by representatives from local government authorities and religious and traditional leaders participated in interviews. Focus group discussions were conducted with farmers and pastoralists as well. Other data were collected through existing documents relevant to the conflict between farmers and pastoralist. Qualitative data were analysed using content analysis where by a combination of elements of analysis were employed to come up with information or themes. Quantitative data were analysed using statistical package for the social science (SPSS) and results were presented by description. 


\section{Results and Discussion}

\subsection{Demographic Characteristics}

The socio-economic characteristics of the respondents were examined in relation to the conflict between pastoralists and farmers. Household background information includes general characteristics of respondents in terms of sex, age, level of education, and main occupation.

Table 1. Socio-Economic Characteristics of the Respondents (Pastoralists and Farmers)

\begin{tabular}{|c|c|c|}
\hline Social-Economic Variable & \multicolumn{2}{|c|}{ Distribution } \\
\hline Sex of respondents & Frequency & Percent \\
\hline Male & 60 & 54.5 \\
\hline Female & 50 & 45.5 \\
\hline Age of Respondents & & 9.1 \\
\hline 20 to 30 & 10 & 29.1 \\
\hline 31 to 40 & 32 & 43.6 \\
\hline 41 to 50 & 48 & 18.1 \\
\hline 51 -Above & 20 & \\
\hline Level of Education & & 13.6 \\
\hline No formal education & 15 & 54.6 \\
\hline Primary education & 60 & 18.1 \\
\hline Secondary education & 20 & 13.6 \\
\hline Others (College \& University) & 15 & \\
\hline Main Occupation & & 49.1 \\
\hline Livestock keeping & 54 & 50.9 \\
\hline Farming & 56 & \\
\hline
\end{tabular}

Source: (Field Data, 2019)

In this study, $43.6 \%$ of the respondents were between the age of 41 and 50 years while $29.1 \%$ were between 31-40 years old. This implies that majority of respondents were within the active and working age group and responsible for decision making. In terms of sex distribution, $54.5 \%$ of the respondents were male and $45.5 \%$ were female. This implies that both groups had almost an equal chance to provide data. With regard to the level of education, this paper assumed that the higher the level of education, the higher the ability of addressing issues confronting the two groups (pastoralists and farmers). It is believed that the ability of an individual to highly analyse a situation lessens clashes, which could result into loss of life and properties (Bengesi\& Abdalla, 2018). The fact that 68.2\% (majority) of the respondents had low levels of education may explain the persistence of recurrent conflicts between the two groups. 
With respect to the main occupation, there were slight differences between farmers and pastoralists. The study found that $50.9 \%$ were engaged in farming while $49.1 \%$ were pastoralists. This suggests that there was almost an equal distribution of the two groups in the study area, which implies that throughout the year, there is competition for farming and grazing land by the two groups.

\subsection{Factors Accounting for Recurrence of Farmers-Pastoralists Conflict}

\subsubsection{Unethical Practices}

This paper reveals that unethical practices such as corruption and deliberate destruction of crops and properties contribute to the recurrence of conflicts as illustrated in Table 2 below.

4.2 Table 2 Factors Accounting for Recurrence of Farmers - Pastoralists Conflicts $(n=110)$

\begin{tabular}{|l|c|c|}
\hline Socio-Economic Attribute & \multicolumn{2}{|c|}{ Distribution } \\
\hline Consequences of Environmental Factors & Frequency & Percentage \% \\
Search for water and pastures & & 91.8 \\
Decrease in Land Fertility & 101 & 45.5 \\
\cline { 2 - 3 } Migration from one Place to Another & 50 & 52.7 \\
Drought & 58 & 61.8 \\
& & \\
\hline Unethical Practices & 68 & 77.3 \\
\hline Corruption & 85 & 56.4 \\
\hline Destruction of crops and properties & 62 & \\
\hline
\end{tabular}

\section{Source: Field data (2019)}

Findings reveal that $61.8 \%$ of the respondents agreed that drought is one of the factors determining the use of natural resource thereby resulting into conflicts while $45.5 \%$ of the respondents identified decline in land fertility as a source of conflicts. Similarly, literature has shown that competition for scarce natural resources such as water aggravates the frequency of droughts (Opiyo et al.; 2011, Opiyo et al., 2012; Laiser, 2016; Falanta et al.,2018). 
Also, $91.8 \%$ of the respondents identified search for water points and pasture as the main factor leading to recurrence of conflicts between farmers and pastoralists. However, the search for water points and pastures for pastoralists is related to lack of land security that rural producers subsist on.

Moreover, $52.7 \%$ of the respondents established that migration from one area to another is one of the factors responsible for recurring conflicts between farmers and pastoralists. This is supported by Mung'ong'o and Mwamfupe (2003) who were confronted with loss of grazing land due to several geographical factors and political marginalization. Some Sukuma and Masai have migrated to and/or taken up other economic preoccupation in addition to livestock keeping in different parts of Tanzania.

Furthermore, the study found that $77.3 \%$ of the respondents agreed that corruption by village leaders is one of the factors responsible for recurring conflicts between farmers and pastoralists.

This is evidenced by the response from one respondent who pointed out that "The increasing rate of corruption among village leaders who sell land illegally is mostly the reason for these land conflicts... when village leaders sell land, they sometimes double sell it to both farmers and pastoralists and as a result when we cultivate our crops the pastoralists also feed their cattle there... That is how conflicts begin and when you go to court you find that the land was illegally sold to both"

Also,deliberate destruction of crops and properties was another cause of conflicts mentioned by respondents. In this regard, $56.4 \%$ of the respondents attribute grazing on subsistence crops as a factor leading to conflicts between farmers and pastoralists. Most pastoralists lead their herds of cattle into farmers' cultivated fields to graze at night in the course of migration.

\subsubsection{Policy and Regulatory deficiencies}

The land policy in Tanzania (through the land Act No. 4 of 1999 and village land Act No. 5 of 1999) classifies land as: Reserved land; village land, and general land. Reserved land is statutorily protected as national parks, land for public utilities, wildlife and game reserves, and other land designated by sectoral legislation. Village land is land which is within demarcated or agreed boundaries of any Tanzanian village. This land is under the managerial authority of village councils, which are answerable to village assemblies (Mwamfupe, 2015; Bengesi et al., 2009).

General land is categorised as residual category and includes all public land which is not reserved land or village land. This also covers unoccupied or unused village land. The definition of general land is ambiguous because unoccupied or unused village land is considered as "excess" and thus falls under the 
jurisdiction of the land commissioner rather than village authorities. The seemingly unoccupied village land may be important areas for seasonal livestock grazing and other important livelihood uses (Mattee and Shem, 2006). Certainly, this ignores the fact that as the population grows, excess village land will actually be brought into use. However, this is actually the same land, which is in most cases identified as suitable for agricultural investment.

Thus, pastoralists occupying semi-arid areas are often subject to efforts to alienate these customary pastures and land holdings for purposes of commercial investments of wildlife conservation areas (Mattee and Shem 2006).

Table 3: Regulatory framework

\begin{tabular}{|l|c|c|}
\hline & \multicolumn{2}{|c|}{ Distribution } \\
\hline & Frequency & Percentage \% \\
\hline Insecurity of land tenure & 67 & 60.9 \\
\hline Ignore to observe demarcation & 57 & 51.8 \\
\hline Beacons removed deliberately & 52 & 47.2 \\
\hline Lack of specific area for grazing & 40 & 36.4 \\
\hline
\end{tabular}

Source: Field data (2019)

Findings reveal that $60.9 \%$ of the respondents affirmed that there was insecurity of land tenure which is associated with land policies and $51.8 \%$ of the respondents confirmed that they ignore land demarcations set up while $47.2 \%$ of the respondents affirmed that beacons were deliberately removed. In view of this, the land policy has some deficiencies because it does not guarantee security of tenure to some users, especially smallholder groups. According to Bengesi (2014) and Bengesi et al., (2009), unsecured land tenure system in Tanzania is accountable for the underdeveloped land resource in the country. Secure land tenure systems allow investment on land, which could partly address most land use conflicts we observe today.

Similarly, among factors leading to recurrent conflicts between farmers and pastoralists is lack of security on land that rural producers subsist on (Hussein et al., 1999) 36.4\% of the interviewees claimed that there 
was no specific area, which the government of Tanzania had set aside for grazing. In this case, pastoralists operate under challenging conditions to secure adequate land for their livestock.

\subsubsection{Overstocking}

Increase in livestock is one of the factors leading to recurrent conflicts between farmers and pastoralists. The occurrence of such conflicts is generally attributed to growing pressure on natural resources use, caused by large herds and increase in cultivation. Figure 1 shows the number of cattle owned by pastoralists in the study area whereby 33.6\% owned herds of cattle between 101 and 150 in number, while 50\% owned between 1 and 100 cattle. Those who owned 151 up to 300 cattle were $13.8 \%$ and $2.7 \%$ owned herds of cattle of above 300 in size. From these results, it can be concluded that over stocking is one of the main factors which fuels conflicts between farmers and pastoralist. These findings are in line with the argument of Ringo et al., (2018) who reported that overstocking is common because it is a symbol of wealth and respect among Masai communities.

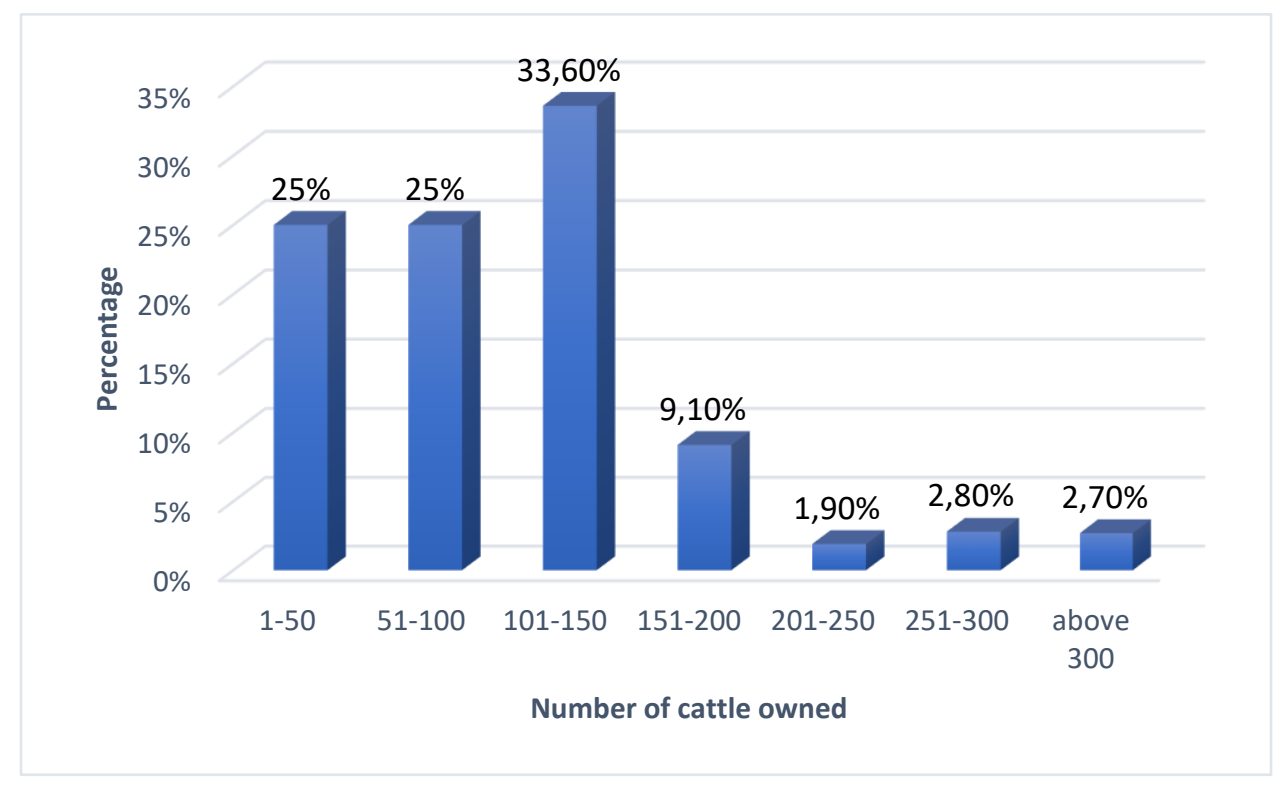

\subsubsection{Increase in both human \& livestock population}

Table 4 shows that $71.8 \%$ of the respondents agreed that increase in human and livestock population is one of the causes of conflict between farmers and pastoralists. This is support by (the census statistics which showed that in 2010 the population was 229,846, in 2011 it was 234,150, and in 2012 it was 265,203). Both farmers and pastoralist with their herds kept increasing in number, demanding for more land and drawing 
the conclusion that "the land is not expanding but population increases." The increase in population of both human and livestock depends on land resource, which itself never increases. Increased demand for land by both farmers and pastoralist as they increase in population leads to conflict. The same was revealed in a research done by (Odhiambo, 2003; Mwambashi, 2015) who found that population pressure leads to increase in tensions and conflicts between farmers and pastoralist, soil erosion, and human rights abuse.

\subsubsection{Nature of Approaches used to Resolve and Manage the Conflicts.}

Part of the reason for the persistence of farmers and pastoralists conflicts lie in the way conflicts are being handled. The use of excessive force involving the police is not only unsustainable but also deepens the hatred between the conflicting parties. At best, this approach is good for imposing short-lived peace but does not resolve conflicts in the long run. The findings of the current study indicate that $65.5 \%$ of respondents confirmed that the nature of approaches used to resolve and manage conflicts is one of the factors leading to farmers-pastoralists conflicts.

Table 4: Other Factors $(\mathrm{n}=\mathbf{1 1 0})$

\begin{tabular}{|l|c|c|}
\hline & \multicolumn{2}{|c|}{ Distribution } \\
\hline & Frequency & Percentage \% \\
\hline Increase in population both human \& livestock & 79 & 71.8 \\
\hline $\begin{array}{l}\text { Nature of approaches used to resolve and } \\
\text { manage the conflicts }\end{array}$ & 72 & 65.5 \\
\hline
\end{tabular}

Source: Field data (2019)

\section{Conclusion and Recommendations}

This paper explored factors leading to conflicts between farmers and pastoralists. It was observed that socio-economic factors, overstocking, political factors, limited land resource, violation of rules and regulations, unknown land marks, beliefs, population growth, and others are the key drivers of conflicts between farmers and pastoralists at Kambala village in Mvomero District. Therefore, the paper argues that pastoralist activities such as grazing and search for water highly cause conflicts. The findings show that farmers are often more vulnerable to such conflicts because they are in sedentary settlements. Again, policy deficiencies and contradictions have been exploited by corrupt elites to the detriment of poor farmers and pastoralists.

Moreover, because farmer-pastoralist conflicts continue to persist without resolution, it is recommended that land laws and district by-laws should be employed to end the problem. Land laws should be applied and enforced by relevant authorities such as the judiciary and local governments to curb the existing conflicts. Farmers and pastoralists should be advised and educated by various stakeholders like extension agents and NGOs on best practices for crop and livestock production to ensure sustainable land use and pasture production. 
Since it has been found that there is increasing demand for water, pasture, and fertile land for farming, the study recommends that, capacity building should be extended to both farmers and pastoralists by the government and NGOs to build relevant infrastructures for rain water harvesting, which can be used for various purposes (livestock, domestic, irrigation, and pasture production). Farmers should avoid expanding land by using improved crop varieties and inputs in crop production and pastoralists should be educated to keep fewer animals while diversifying into other economic activities to limitencroaching other peoples' land in search for nutritious pastures.

Resolving farmer pastoralists conflicts is not a politics issue and should not therefore be taken as a political agenda. Conflicts should be resolved using land laws and relevant authorities should ensure that human right are protected and any bod who contravenes the established laws should be dealt with accordingly.

The study found that climate change is the main cause of drought and water scarcity leading to farmer pastoralists conflicts. It is recommended that farmers should be given assistance to cope with the situation. Farmers should be educated on the presence and continuity of climate change it variability impacts, and the need to change life styles, production systems, and general ways of earning income in order to adapt to the prevailing situation. Farmers and pastoralists should be given input subsidies in order to use land resources economically. The two parties should be advised to form cooperatives through which they will have bargaining power to increase their product process and market them for profit. This will ultimately increase their household incomes.

The government should be keen on balancing investment interests and the livelihood of its people. The ongoing green grabbing which targets rangeland and protected areas has excluded pastoralists. Business projects must pot the interests of the people at centre.

Strong institutions and good leadership are vital in addressing land use conflicts between farmers and pastoralists. Corrupt leaders have benefited enormously from such conflicts. This is an area that $\mathrm{n}$ needs to be seriously scrutinized.

Civil society organizations and other development actors should ensure that communities are organized to address their own challenges. This can be done by encouraging communities to openly discuss matters that affect them and ask difficult questions which hold their leaders accountable.

\section{References}

Adelakun,O. E., Adurogbangba, B, and Akinbile, L.A. (2015). Socioeconomic Effects of Famer-Pastoralist conflict on Agricultural Extension service Delivery in Oyo state Nigeria. Journal of Agricultural Extension 19, (2),.59-70. http:// dx.doi.org/10.4314.jae. v 19i2.5

Adeoya, N.O. (2017). Land use conflict between farmers and herdsmen in parts of kano Yobe and Borno states of Nigeria: Nomads viewpoints.Ghana journal of Geography, 9 (1), 127151 Retrieved from https: www.ajol.info/index.php/gjg/article/download/154660/144240.

Amin, A. (2005). Social Science Research, conception methodology and analysis. Kampala: Makerere University Printer.

Bailey, K., (1994). Methods of social Research fourth Edition, New York: The Free press. 
Bengesi, K.M.K and Abdalla, J.O. (2018). Forces Driving purchasing behaviour of tourist Hotel along Tourist Agricultural Supply Chain in Zanzibar, International Journal of Marketing.10(2) 150 - 168 https//doi.org/10.5539/ijms. vion2p36.

Bengesi, K.M.K. (2014). Assessing, Impact of Biofuel Investments on local Livelihoods in Tanzania. A case of Kisarawe Bagamoyoand Kilwa Districts. Retrieved from http/www.mviwata. org/ wpcontent/uploads/2014/09/study - Report- on Biofuel- Investment July 2012.pdf studies, Accessed on January 7, 2019.

Bengesi, K.M.K., Msuya C.P., Salanga, R.J \&Mwakalobo, A.B.S. (2009). Implication of $\quad$ Biofuel production on food security in Tanzania. Retrieved from http://www.actionaid.org/sites/files/actionaid/implication-o-biofuels-production-on foodsecurity-in-tanzania .pdf.Accessed on February 20, 2019.

Benjaminsen, Tor., Faustin, M., and Jumanne, M. A. (2009) The KilosaKillings: Political Ecology of a farmer - Herder conflict in Tanzania.Development and Change. The Hague: Institute of social studies.10(2),150-168.https://doi.org/10-1111/j.1467-7660.2009.01558.x

Boundless, (2016). The conflict perspective. Retrieved from http://www.boundless.com/sociology/texbook/sociology-1/theoretical-perspective- in-sociology24/the- conflict- perspective-156-974.Accessed on February 20,2019.

Crossman, A. (2016).Understanding conflict theory: A brief overview. Retrieved form http://www.throughtco.com/conflicttheory-3026622. Accessed on January 10, 2019

Deutsch, M (1991) Subjective feature of conflict resolution: psychological, social and cultural Influences. In New direction in conflict theory, edited by vayrnen, London pp 26-56.

FAO. (2005). Global forest Resources Assessment 2005- progress towards sustainable forest management. FAO Forestry Paper No. 147. Rome. Retrieved from www.fao.org/docrep/3/a0400e/a0400e00.htm

Flanta, E. M \& BengesiK.M.K. (2018) Druers and consequences of Recurrent conflict between farmers and pastoralists in Kilosa and Mvomero Districts, Tanzania, Journal of sustainable development 11(4) 13-26.

Hussein, K., Sumberg, J., and Seddon, D. (1999). Increasing violent conflict between Herders and Farmers in Africa. Claims and evidence. Development Policy Review 17 (1999) 397- 418.Retrievedfrom www.acadeic-

edu/1119608/increasing_violent_conflict_berween_harders_and_farmers_in_Africa_claims_and_ev idence (https:// Doi.org/10.1111/147-7679.00094.)

Judex, M., Thomm, H.P., and Menz, G. (2003). Modelling of land- use changes in a West Africancatchment, Center for Remote sensing of land surfaces, University of Bonn, 53113 Bonn, Germany. Retrieved from www.isprs.org/proceedings/xxxvi/part 7/pdf/069.pdf. Accessed on March 13,2019.

Kothari, C.R. (2008). Research Methodology, Methods and techniques (2nd Ed., Pp.109 - 110) New Delhi. New Age Inter- national $(\mathrm{P})$ Limited

Laiser, T.J. (2016). Land tenure system and conflict in rural smallholder (Master Dissertation, Sokoine University of Agriculture, Morogoro, Tanzania).

Mancasu, N, snyder, R.L, Kyriakakis., and Spano, D. (2015) water scarcity and future challenges for food production, Water 7 (3), 975- 992 http://doi.org/10.3390/w 7030975.

Massay, G.E. (2017) In search of the solution to former- pastoralist conflicts in Tanzania, SIIA Occasional Paper, 257 pp.1-17 Retrieved from www.saiia.org.za/research/in-search-of-the-solution -to-farmerpastoralist-conflict in-Tanzania. Accessedon February 22, 2019.

Mattee, A.Z and Shem, M. (2006). A review of current policies and law that touch on pastoralism in Tanzania. Issue paper, (140).IIED,London,UK. 
Mung'ong'o, C, \&Mwamfupe, D. (2003). Poverty and changing livehoods migrant Maasai pastoralists in Morogoro and Kilosa districts, Tanzania. Research on poverty alleviation.

Mwambashi, E.P. (2015). Assessing the impact of land conflict between farmers and pastoralists in Tanzania, Ulanga district council (Master. Dissertation,Mzumbe University, Tanzania.

Mwamfupe, D. (2015). Persistence of farmer - herder conflicts in Tanzania. International journal of scientific and research publication, 5(2), 1-8. Retrieved from www.ijsrp.org/research-paper-0215/Ijsrpp3862.pdf

Norman, A.S. (2013) Challenges of Managing Election in Africa. International Journal of Business Economic and Management, Research 3 (5) 1-7. Northern parts of Tanzania from land administration

Odhiambo,M. O. (2008). Conflict in Ngorongoro District, Causes consequences and possible solution Ngorongoro .NGO Network

Orindi, V.A.,Nyong, A, and Herroro, M. (2007) Pastoral livelihood Adaptation to Drought and Institutional Interventions in Kenya. Human Development Report 2007/2008, Fighting climate change: Human solidarity in a divided world. United Nations Development programme. Occasional Paper 54. New York. Retrieved from http://cgspace.cgiaar.org/handle/10568/2511.Accessed on February12, 2019.

Opiyo, F.E.O, Murathi, S.M \& Ngugi, R.K. (2011) The influence of water availability on pastoralist resource use in Mwingi and Kitui District in Kenya.Journal of Human Ecology, 35 (1), 43-52. https://doi-org/10.1080/09709272.2011.11906389.

Opiyo, F.E.O, Wasonga, O.V., Schilling, J. \&Murwthi, S.M (2012) Resorces - based conflicts $\quad$ in drought - prone North - West Kenta: The drivers and mitigation mechanism. WUDPECKEP Journal of Agricultural Research, 1 (11), 442-453. Perspective. Queensland, Australia: ITC

Ringo, J.J., Bengesi, K.M.K, \&Mbango, M.C.Y. (2018). Access and challenges of health facilities amongst Agro-pastoralist communities in Handeni District, Tanzania. Journal of population and social studies, 26(1)218-229. Doi:10.2513/JPSSv26n3.014

Semberya, D. (2014) Farmers, pastoralists conflicts: where have failed. The Guardian Newspaper, (January). Retrieved from http://www.ippmedia.com/fronted/?/= 63745

Tonah, S. (2006). Managing farmer- herder conflict in Ghana. Ibadan Journal of social sciences, $\quad$ 4(1), 3545.

Wehrmann, B. (2008). Land conflicts A practicalquide to dealing with land disputes. Deutsche Gesellschaft fur TechnischeZusammenarbeit (GTZ)Gmbll56726 Eschbon, Germany.pp.122. Retrieved from www.researchgate.net/publication/42766163_Land_Conflicts_A_Practical_Guide_to_Dealing_with _Land_Disputes. Accessed on February 12, 2019. 